\title{
Interdisciplinarity as a Source of Relevance for Political Science
}

\author{
Philipp Decker ${ }^{1, *}$, David F. J. Campbell2, ${ }^{*}$, Jürgen Braunstein ${ }^{3, *}$ \\ 1 Social Sciences University of Ankara, Department of Political Science and Public Administration, Turkey \\ 2 University of Vienna, Department of Political Science, Austria \\ 3 Harvard University, Kennedy School of Government, United States of America \\ * philipp.decker@asbu.edu.tr, david.campbell@univie.ac.at, juergen_braunstein@hks.harvard.edu
}

\begin{abstract}
This article seeks to shed light on the critical role of interdisciplinary qualities for the societal relevance of Political Science. It traces the historical development of Austrian Political Science embedded in the larger international context and by considering the cases of the United States, France, Germany and Italy. It serves as a means to demonstrate the close linkage between interdisciplinarity in Political Science and its professional, political and civic relevance. By addressing the question of Political Science's societal relevance from a historical and cross-national perspective, it prepares the ground for consecutive studies that conduct in-debt comparative analysis
\end{abstract}

\section{Keywords}

interdisciplinarity, relevance, political science, Austria

\section{Interdisziplinarität in der Politikwissenschaft als eine Quelle der Relevanz}

\section{Zusammenfassung}

Dieser Artikel versucht, die kritische Rolle von interdisziplinären Qualitäten für die gesellschaftliche Relevanz der Politikwissenschaft aufzuzeigen. Er verfolgt die historische Entwicklung der österreichischen Politikwissenschaft, eingebettet im größeren internationalen Kontext und unter Berücksichtigung der Fälle der Vereinigten Staaten, Frankreichs, Deutschlands und Italiens. Der Artikel dient dazu, die enge Verbindung zwischen Interdisziplinarität in der Politikwissenschaft und ihrer beruflichen, politischen und zivilgesellschaftlichen Relevanz aufzuzeigen. Die gewonnen Erkenntnisse legen nahe, dass Interdisziplinarität eine wichtige Quelle für die gesellschaftliche Relevanz der Disziplin ist und legt den Grundstein für Folgestudien.

\section{Schlüsselwörter}

Interdisziplinarität, Relevanz, Politikwissenschaft, Österreich

The authors have declared that no competing interests exist. 
Society has problems, and the universities have their disciplines. ${ }^{I}$

Peter Heintel, Professor at Alpen-Adria-University Klagenfurt

\section{Introduction}

This article investigates the relevance of Political Science (PS) in Austria by looking at the historical trajectory of interdisciplinarity in Political Science. It addresses the question of whether the interdisciplinarity of Political Science and its societal relevance are linked. That is done through a historical case study on "Interdisciplinarity and Relevance of Austrian Political Science I763-1980" and by considering the cases of discipline formation in the United States, Germany, Italy, and France. This article shows that although structural and cognitive closure are intrinsic to the formation of disciplinary boundaries, the interdisciplinary qualities of Political Science influence its professional, political and civic relevance. If there is a lesson to be learned, it is that interdisciplinary qualities are essential to creativity and innovation in a number of fields, including: political research in terms of problem and policy orientation, as well as for the education of professionals in the political-administrative domain.

Unlike existing studies on the history of Austrian PS (e.g. Pelinka 1996, Sickinger 2004, Ehs 2010, König/ Ehs 2OI2), the present study embeds the case of Austrian PS and its predecessors in a broader international context. $^{2}$ Thereby we engage with the current debate on the societal relevance of PS (Smith 2015, Donovan/ Larkin 2006; Wood, 20I4; Cherney et al. 20I3; Capano/ Verzichelli 20I6) and the discipline's engagement in interdisciplinarity (Warleigh/Cini 2009, Ashworth 2009). The latter can be viewed as a response to multiple pressures including the demand for problem-orientation in the allocation schemes for research funding and the prominence of "new issues that cross established disciplinary boundaries" such as politics of public health, climate change, cyber security, and so forth (Warleigh/ Cini 2009, 4).

This article brings the story back to the era of Austrian state-building in the eighteenth-century, which helps identifying the drivers behind interdisciplinary traditions of political science. Beside the political demand for a "science of the state" that guides political reforms and economic policy, there was also a professional demand for standardised higher education in the politicaladministrative domain, as well as a civic demand for in-

I See CERI (I982, I27) and also Arnold (20I3, IIO5).

2 A rare study of Austrian Political Science that also engages with the discipline in another country has been conducted by Reinhard Heinisch. See Reinhard Heinisch (2004). formed public discourse on controversial issues.

In the early twentieth-century Austrian social sciences flowered for a brief period, following a larger trend that resulted in the consolidation of PS as a discipline in countries like the United States, Italy, and France. Against this background it seems paradoxical that while Austrian (and "old Austrian") émigrés succeeded in taking up prominent positions as social and political scientists in the United States in the I940s and I950s, in Austria PS suffered from a general lack of relevance. It is useful to follow Senn and Eder's (20I8, I-I8) threefold definition of relevance of PS by distinguishing between civic, political and professional relevance. The lack of professional and political relevance is reflected in the secondary status of PS in the public and professional sectors vis-à-vis other disciplines (König/Ehs 2012, 218-19). Unlike in other countries, the discipline of legal science (law) has for long held a monopoly on "state affairs" and the training of professionals for the political-administrative domain (Ehs 20IO, 237).

In his discussion of the current state of Austrian PS, König (2OII, 83) argues that the discipline appears incapable to adapt its theoretical and methodological instruments in order to deal with pertinent societal problems. He further observes a lack in communication and cooperation on the national and international level (ibid., 85). ${ }^{3}$ This deficiency within the discipline also hints at the lack of inter-disciplinary qualities, which above all require shared epistemological foundations in order to engage in dialogue and collaboration. The lack in cooperation undermines the generation of major new knowledge surplus, methodological innovation, the development of theories, and ultimately also the ability to inform political decision-making and the public on pivotal societal questions.

\section{The study of politics as disciplinary and interdisciplinary endeavour}

Interdisciplinary qualities enable political scientists to borrow from different theoretical and methodological traditions and to engage in cooperation across sub-disciplinary and disciplinary boundaries in order to address societal problems. This "may generate not only new ways of understanding key problems, but also novel means of studying them", which is particularly critical for issues that "have recently shown on the radar screens of political scholarship" (Warleigh/Cini 2009, IO). Examples are the study of environmental politics and climate change, migration and integration, electronic currencies, cyber security and cyber warfare, quality of democracy in a global

\footnotetext{
3 This point is supported by a similar observation concerning the lack of cooperation in Austrian sociology. See for a discussion Christian Fleck (2002).
} 
context (for example, see Campbell 2019), and so forth.

There is a broad consensus that the disciplinary framework of PS is a requirement for the "the systematic, self-reflexive, and institutionalised" study of politics (Senn/Eder 2018, 4). It is the disciplinary framework, comprising shared traditions, codes and practices, which enables division of labour and "facilitates collaborative attacks on common problems" (Goodin 2013, 8). Corresponding to the nature of the investigated problems, interdisciplinarity refers to the crossing of disciplinary boundaries by drawing on the insights of scholarship in other disciplines with a potential for reflexivity that "applies to methodology as well as to theory and the body of empirical literature" (Warleigh/Cini 2009, IO).

The most common argument for interdisciplinarity in political research is the complexity of multi-faceted real-world problems (Wagner et al. 20II, Gibbons I994, Klein 1990). This engagement takes place on a continuum, ranging from multidisciplinary, to interdisciplinary, and transdisciplinary modes of research (Van den Besselaar/Heimericks 200I, 2). Multidisciplinarity refers to scholarship that draws on different disciplines, which are "used in parallel rather than in conjunction" (Warleigh/Cini 2009, 9). Interdisciplinarity on the other hand refers to an "integrated study based on explicitly harnessed insights and methods from various disciplines, using agreed common terms and methods" (ibid.). Transdisciplinarity again emphasizes research cooperation between academic researchers and practitioners, drawing on expertise from a wider range of organizations and integrating research from different disciplines with the knowledge of stakeholders in society (Wagner et al. 20II, I6).

The expectation to make research more relevant to society through increasing collaboration within and across disciplinary boundaries affects social science at large. A citation analysis of a longitudinal sample of 35,296 business and management scholars showed that scholars' cognitive openness to other disciplines and their structural openness to broader collaborations influence their academic impact (Belkhoujaa/Yoon 20I8). Whereas moderate levels of cognitive openness and structural openness increased young scholars' citations, a high level of cognitive openness and a low level of structural openness increased those of senior scholars (ibid). Within PS, a citation analysis on ten volumes of Oxford Handbooks of Political Science shows that only seven authors are influential across all sub-disciplines, including comparative politics, political behaviour, law and politics, political economy, methodology, political theory, international relations and public policy, while I85 authors impact on more than half of them (Goodin 2013, I8). The scholars with the highest academic impact are those who are able to cross the borders of sub-disciplines (ibid.).

\section{Interdisciplinarity and Relevance of Austrian Political Science 1763-1980}

Before looking comparatively at the pathways of discipline formation with the aim to shed light on the question whether interdisciplinarity in PS and societal relevance are closely linked, such an endeavour requires a clarification of semantics. As a number of scholars have argued previously, one can identify different currents of science of the state (Staatswissenschaft), political economy (Nationalökonomie, Kameralistik), and administrative science (Verwaltungswissenschaft) as historical predecessors of what has become consolidated in the twentieth century as PS (Wagner 1990, Heinisch 2004, Dvorak 2OII, König/Ehs 2OI2). As each of the considered countries developed its own distinct tradition of PS, the comparative perspective enables us to identify variation in the interdisciplinary qualities of PS as well as variation in societal relevance.

\subsection{The interdisciplinary predecessors of political science in the era of state-building}

In the European context of eighteenth-century military competition between states, the modernisation projects of absolutist rulers increased the demand for applicable knowledge for state-reforms and governmental policies. Driven by the contemporary demands of military-fiscal states in the making, the respective "science of the state" has been exercised as a problem-oriented enterprise that comprised early forms of what later became known as economics, PS and sociology (Wagner 1990, 47I).

In Austria, the institutionalisation of PS goes back to 1763, when Joseph von Sonnenfels was appointed to the newly established chair for "police and cameral science" (Polizey- and Kameralwissenschaften) at the philosophical faculty of the University of Vienna (Ehs 20IO, 226). Essential for the development of an interdisciplinary science of the state and politics - what became referred to as Staatswissenschaft - was that the modernising elites of Enlightened Absolutism facilitated the connection between political theory and political practice (Dvorak 20II, 20). Sonnenfels' concept of "policing", a fusion of "polis" (the state) and "polire" (to polish), refers to what can be called policy. This explains why the concept of Polizey/policing was closely related to Cameralism, which represented the Austrian political economic model of mercantilism. Its assumption was that "the social, economic and cultural conditions of the country's population..., once ascertained and monitored, could be purposefully improved and advanced through 'police' activity" (Poggi 1990, 50-5I). In modern PS terms, this notion of "police activity" refers to what can be described as regulation and public policy, involving a variety of policy fields including fiscal system, migration, 
health, education, security and so forth.

In 1784 the Chair of Cameralism at the University of Vienna was transferred to the faculty of law. In consequence, subjects and courses such as police science, trade science, agriculture, taxation and public statistics were incorporated into the juridical degree programme, which increased its interdisciplinary qualities (Ehs 20IO, 227). This highlights the second major function of contemporary Staatswissenschaft, beside its primary function of basic and applicable knowledge production for government: the production of ideal-typical bureaucrats. The higher education of civil servants was initially aimed at instilling a progressive statist ethos into students, to turn them into the cadres of the respective modernist political project.

At this point it is worth highlighting the impact of Sonnenfels' interdisciplinary practice of Staatswissenschaft on all three aspects of relevance. A biographical summary of Sonnenfels reads as follows: "The greatest authority in the field of administrative science, he combined an administrative career with rigorous academic, literary and journalistic activities" (quoted in Dvorak 20II, 2I). In terms of political relevance, Sonnenfels played an important role in political decision-making and was directly involved in the drafting of the Austrian civil code and policies reforming the police. Concerning professional relevance, Sonnenfels shaped academic scholarship in the field of political economy and public administration, as well as the curriculum of the higher education of civil servants. The textbook he produced was to be taught to all future bureaucrats educated at the university of Vienna. Sonnenfels was also aware of the importance of civic relevance. Sonnenfels' practices were characterised by a continual effort to combine theory development, political practice and policy advice, the education of bureaucrats, and the creation of a politically informed public (Dvorak 2OII, 2I). The literary and journalistic activities of Sonnenfels were in fact complementary to his academic research, teaching and policy-making, affecting public discourse on controversial political issues.

\subsection{Conservative opposition to the interdisciplinary tradition of Staatswissenschaft after 1790}

The decades after 1790 saw the abandonment of Sonnenfels interdisciplinary tradition of Staatswissenschaft and the formation of "law" as a discipline separated from "politics". In fact, the conservative governments after 1790 enforced the removal of state theory and of concepts such as "the political" and "the state" from university curricula. This was a critical break with the Enlightenment tradition of state-centred PS in Austria. Empirical political research and theory development were replaced by a conservative type of administrative science education that was reduced to the legal tradition, complemented with religious and metaphysical subjects.

This shift elevated the status of law as a discipline in the making and abolished the interdisciplinary tradition of administrative and state science. The historical background was that after the French Revolution, political reformism became increasingly associated with radicalism and Jacobinism, which paved the way for a conservative regime response in Austria. Within Austrian universities, the government removed all references to the state and to normative political theory, with the goal to erase the "state myth" (Heindl 2013, 76). Emperor Francis fiercely opposed the recruitment of what he called "patriots", "friends of literature", "Projektmacher" and "critics" (ibid., 80). Instead of facilitating a science of politics that informed political action, the reformed education for the political-administrative class served the function to legitimise the political status quo. In this context, the government introduced a new regulation in 1795, which made the graduation in legal studies a mandatory requirement for bureaucrats (Stimmer 1997, 63). The result was that the law department and legal studies became the central instrument for the selection and recruitment of Austrian bureaucrats (ibid.).

The primary function of Staatswissenschaft within the faculty of law was accordingly redefined as to secure the production of pious and loyal civil servants instead of educating "scientists" and "intellectuals". The curriculum reform of 1793 removed all courses on political theory, reducing the former Staatswissenschaft to political economy, with courses in economics, economic policy, finance and financial legislation (Ehs 2010, 227). In I805, religion was officially added to the curriculum of juridical studies. Its weight was further increased in 1824 with the introduction of additional courses in moral philosophy, science of religion and metaphysics (Heindl 2013, I43). The aim was to promote students' education as Catholic "moralists" and loyal administrators, instead of enlightened "scientists", who investigated politically relevant problems of the state (ibid., I3I).

A similar current of interdisciplinary science of state affairs in the Cameralist tradition developed in Germany and France. In contrast to Austria, the policy and state oriented Staatswissenschaft was maintained in many German universities within philosophical or staatswissenschaftiche faculties until the early twentieth century. In France, there were similar attempts to consolidate a current of early PS in the interdisciplinary tradition of Staatswissenschaft, with an explicit focus on the education of bureaucrats and political elites. One prominent effort was the plan to establish an Ecoles speciale des science politiques in I795 (Wagner 1990, I79). One argument was that the graduation from "moral and political sciences" would secure the education of a Republican political elite (ibid.). This approach illustrated the French focus on 
the political-administrative domain. In the period after I815, in the European context of conservative restoration after the Napoleonic Wars, these efforts were recurrently turned down due to the opposition of the professionalised legal sciences (ibid., I80).

\subsection{Interdisciplinarity and the consolidation of political science traditions in the late nineteenth and early twentieth century}

This section discusses the consolidation of PS as a discipline, which gained much of its utility for governments and political elites from interdisciplinary qualities. In countries like Italy, France and Germany the context of nation-building in the decades after I870 sheds light on the political demands for a science of politics that was capable to inform modernisation policies in various policy fields as well as to provide a recruitment pool for the expanding state bureaucracies and political parties. Vice versa, the absence of the formation of modern PS in Austria and the continual dominance of legal studies implies a lack in regard to the professional, political and civic functions attributed to the discipline in other countries.

In the last quarter of the nineteenth century, the accelerating processes of industrialisation, urbanisation, and democratisation triggered a variety of new societal problems that were to be tackled by governments. Seeking ways to increase their legitimacy through state expansion and reformism, political elites in the United States, France, Italy and Germany supported the formation of PS as a discipline, which built on the tradition of Cameralism and Staatswissenschaft (Wagner 1990, I62). In contrast, in Austria the traditional dominance of the law departments in educating the state's bureaucrats and political elites - what became referred to as the socalled "Juristenmonopol" in the political-administrative sector - prevented the formation of PS as a discipline.

It is worth pointing out that the institutional and professional consolidation of political or administrative sciences in the United States, France, Italy and Germany were marked by an interdisciplinary approach to the study of state affairs and politics. As a consequence, the formation of PS as a discipline in the United States, France, Italy and Germany had inevitably affected the status of legal studies and law departments. In the United States, academics, who had previously studied Staatswissenschaft in Germany, initiated the institution of the first PS departments in the I890s (Loewenberg 2006, 597). The American Political Science Association was founded in 1903. With its problem-solving and policy orientation, US-American PS succeeded in maintaining inter-disciplinary qualities, extending the function of PS into the public and private sector. This redefined the function of law departments as institutions that provide professional education for legal practitioners, undermining their function in the generation of knowledge for political and state affairs (Ehs 20IO, 23I). Similarly, one reflection of the dominant status of PS was its incorporation of International Relations as one of its sub-disciplines during the I950s (Ashworth 2009, 23).

In France, the modernization project of the Third Republic provided the conditions for the revival of the tradition of the sciences morales et politique, which was founded during enlightened absolutism and had been abandoned by the restorationist regime after 1815 (Wagner 1990, 179). The successful professionalization of French PS is reflected in the foundation of the Ecole libre des sciences politique, the predecessor of the Science Po, in $187 \mathrm{I} / 72$. Following the interdisciplinary tradition, its curriculum included courses in public administration, diplomacy, economics and finance. Its politicaladministrative orientation shaped the image of French PS as being application oriented. In Paris at the Institut d'Etudes Politiques, the country's future public and private-sector leaders are educated, "through a diversified curriculum, of which political science is one component" (Montricher 1989, I48). Although until the mid-I97os, PS was dominated by a narrow definition of politics and focused on "the study of regimes and political parties, public opinions, and electoral behaviour", fields of political research diversified since the I980s: "linguists and computer scientists are researching political discourse; philosophers, historians, and even economists are explaining the origins of the modern State. Topics are multiplying, and scientists differ on how problems should be studied" (ibid.).

In Germany, the problematic of nation-building in the context of achieved national unification stimulated a revival of the Staatswissenschaft. Although the influential legal tradition of constitutional law and idealist state theory rendered the disciplinary consolidation of empirical PS difficult, there developed a science of the state that opened up cognitively and structurally. A prominent example represents Max Weber, who was appointed to the chair of political economy (Nationalökonomie) at the University of Freiburg in 1894. In 1902, he began writings on questions of social science methodology (Kalberg 2005, xvi). Although the dominance of juridical-legal studies in German "administrative science" (Verwaltungswissenschaft) undermined the consolidation of PS as a discipline, the notion of "the political" remained a central component (Wagner 1990, I68-170). Only after WWII, (Western) German political and administrative science began to reduce the influence of the legal tradition by drawing on the policy-orientation of US-American PS. This development is illustrated by a special issue of the Politische Vierteljahresschrift with the title "Gesellschaftlicher Wandel und politische Innovation" (PVS-Sonderheft 4, 1972), which was published following the congress of the German Association of PS in Mannheim I97I. 
In Italy, the context of national unification rendered the problem of nation-building quite similar to Germany. However, in contrast to Germany, there was no established legal tradition that dominated the domain of "state affairs", which provided space for the consolidation of an Italian PS that was characterised by a focus on empirical research, coherent research programs and elaborate concepts (Wagner I990, I76). The major problems that were investigated concerned issues of political rule (especially the relation between the elites and the masses), public institutions, the political system, political economy and national education. Similar to PS in the United States, Italian PS built on the tradition of Staatswissenschaft. It developed the capacity to produce a class of bureaucrats and political elites, as well as to develop theoretically and methodologically coherent research programs that explored the impact of public institutions on society. This was achieved by a consensus among scholars to distinguish between the "legal" state of the country and "factual" reality (ibid., I79). The produced knowledge contributed to political innovation, especially in the field of nation-building (ibid., I77).

In the late nineteenth-century, Austria saw the expansion of public services and democratisation, increasing the complexity of governance and the demand for knowledge production and knowledge application. From a comparative perspective, the neglect of the interdisciplinary tradition of Staatswissenschaft, as a source for the development of an Austrian PS appears striking. Despite the flourishing of economics, statistics and ethnography, Staatswissenschaft remained reduced to an auxiliary science of public law (Ehs 20IO, 227). In response to growing societal problems in the multi-national state, political elites turned to the discipline of law. In the discourse of the Austrian political elite and bureaucracy, all kinds of problems of society, state reform, parliamentarism and democracy were basically not perceived as "political" but defined as "legal" or "constitutional" questions, corresponding to the dominant status of the discipline of law. The character of the Austrian legal tradition reinforced established norms and undermined political innovation. What began in 1790 as a regime response to perceived revolutionary threats, taking the form of abolishing political theory and interdisciplinary traditions of the study of politics, conditioned the ascendancy of law as dominant discipline informing political decision-making and educating graduates to be employed in the political-administrative sector.

\subsection{The regression from interdisciplinary applied re- search to anti-empiricism in the First Republic}

In 1919, in the new context of the First Austrian Republic, Social Democrats began to intensify efforts to revive the interdisciplinary tradition of Staatswissenschaft as an empirical social science (Ehs 2010, 228-29). These efforts were driven by the aim to break with the past and to create political and social innovation. After the collapse of the coalition government in October 1920, the conservative-clerical Christian Social Party was in charge of university reforms, which lasted until the end of the First Republic. The new conservative government countered the previous progressive reform attempts and helped to establish conservative hegemony at Austrian universities. Conservatives warned of the negative impact of "Jewified" universities and demanded their reChristianisation by bringing methaphysics back into science, countering the "nihilistic impulses of individualism, positivism, liberalism, and materialism" (Wasserman 2014, 38-39).

Conservative opposition to modernist thought and empirical social science ranged from mobbing, the exclusion of scholars from universities, to police intervention against scholarly associations such as the Ernst Mach Society. In 1934 Moritz Schlick, one of its founders, defended the society against the government by arguing that it was an unpolitical science association. In fact, the society's activities were "committed to a scientific world-conception that militantly rejected metaphysics, religion, and nationalist pretensions" (Wasserman 20I4, I08) and were thus fundamentally opposed to the ideology of the ruling conservatives. The Leo-Gesellschaft, an academic society for Catholic scholars, was the major vehicle for the conservatives' struggle against the modernist streams of Marxism, Liberalism and Democracy (ibid., 4). As Austria's largest academic organisation it distributed nine scholarly journals (ibid. 20). Its socialscientific section became the defining sub-group that focussed on political, economic and social theory, and "boasted contributions from over a hundred Viennese professors" (ibid., 23-24).

Although conservative hegemony prevented the institutionalisation of modern Social and PS in Austrian universities, the revived interdisciplinary tradition of Staatswissenschaft left its imprint in Austrian social science outside of the universities. It initiated the heydays of Austrian social science marked by methodological innovation and problem-oriented empirical social and PS (Ehs 20IO, 229). Innovative research programmes were developed for instance by the Austro-Marxists and representatives of Nationalökonomie. As the former were associated with socialism, and the latter with liberalism, both became the target of the conservative-clerical government, which gradually removed social-science subjects and restored the conservative character of legal science. Although it was still possible to pursue graduate studies in Staatswissenschaft, a reform in 1926 reduced it again to an auxiliary science of legal studies, resulting in a sharp decline of graduates due to its lack of professional relevance (ibid., 229-30). 
Beside the removal of social-science subjects, the Austrian government also promoted a metaphysical and anti-empiricist type of political and sociological studies. The most prominent figure was Othmar Spann, who was appointed professor of political economy and sociology (Nationalökonomie und Gesellschaftslehre) in the Law Faculty of the University of Vienna in 19I9. His textbook Gesellschaftslehre (1923) became essential for the education of a new conservative generation of graduates. Despite its dominant position in Austria, the Spann Circle became internationally isolated, dismissing contemporary scientific debates in German sociology as "scientistic" and arguing for the necessity of an anti-Enlightenment "sociology of the spirit" (Wasserman 20I4, 88). Nevertheless, Spann succeeded in placing his students in university positions and several full professorships in Vienna and Graz. His growing institutional influence was a symptom of "the conservatism of the university system and the constant interference of the state in scientific matters" (ibid., 7I). Although Moritz Schlick's circle enjoyed international success, Schlick failed to place a single student in a professorship in Austria.

Many of the liberal, socialist, and Jewish scholars that were forced to leave Austrian universities met in private associations, forming interdisciplinary clusters that gave rise to innovative research. Associated with the clusters of so-called Austro-Marxism and the Vienna Circle were prominent scholars like Otto Bauer, Paul Lazarsfeld, Karl Menger, Oskar Morgenstern, Joseph Schumpeter and Karl Popper. The features that were common to both clusters - which enabled cooperation and innovation - were a coherent theoretical school, empirical methodology, accessible language, and interdisciplinarity (Mueller 1996, I6-I7). These qualities contributed to the applicability of produced knowledge, reflected in Austro-Marxism's contribution to "applied social research" (Wagner 1990, 312-20), the Vienna Circle's contribution to the development of modern Game Theory (Leonhard 1998), and the pioneering work of Lazarsfeld in the field of electoral research and political sociology (Jeřábek 200I). In the United States, Lazarsfeld continued the tradition of "applied social research" and created the "Bureau of Applied Social Research at Columbia University (Barton 200I).

Somewhat paradoxically, the growing distance of leading Austrian social scientists to the conservative structures of the universities resulted in growing space for interdisciplinary cooperation. Lacking the financial resources of university departments, many scholars turned to the Social Democratic municipal government of Vienna or the labour movement for funding. These conditions enabled a problem-oriented engagement with subjects, which in turn drove methodological, theoretical and political innovation (Mueller 1996). One example that illustrates its impact on political, profes- sional and civic relevance is the work of Otto Neurath, who belonged to the so-called Austro-Marxists. The figure below shows an illustration that was produced for the Social and Economic Museum of Vienna on the basis of Otto Neurath's statistical survey of social inequality and infant mortality. "By demonstrating clearly to the Viennese working class that infant mortality rates were falling in the poor ghettos, but not as quickly as in the wealthy enclaves ... the museum's pictorial statistics were both a constituent element of Neurath's empirical sociology and an endorsement of a particular politics" (Leonard I998, I0).

Figure 1: Illustrations of Neurath's research findings to inform the public (Source: Leonard 1998, 12)

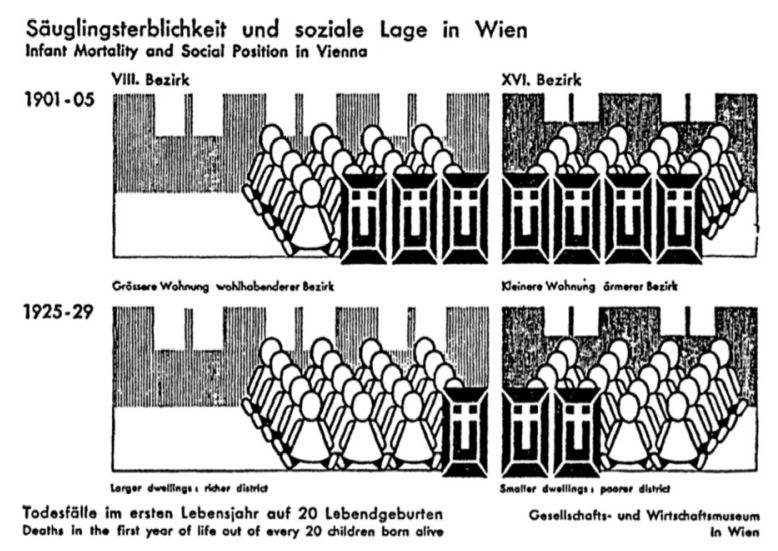

This example, which is selected from a number of similar cases, demonstrates how the interdisciplinary cluster of Austro-Marxism stimulated relevance on the academic level, the political level, and the civic level. The figure above is based on rigorous problem-oriented statistical research, which is situated within an established research program. The analysed data is translated into pictures that deliver an explanatory message to the broader public. Finally, it is part of a larger normative political project, trying to inform the public in a way that broadens the support base of the Social Democratic Party. ${ }^{4}$

The rise of Anti-Semitism, Austro-Fascism (1933/34) and Nazism(1938) led to the emigration of Austria's leading social scientists, many leaving to the United States. In contrast to their marginalisation in Austria, the academic institutions abroad turned out to be receptive of interdisciplinary political research. Examples were the University of Chicago, Princeton, Harvard, Berkeley, Cornell, the Institute for Social Research at Columbia and the New School for Social Research. Beside the fact

4 While in the second Austrian Republic this tradition has largely vanished, it is widely practiced in countries like the United States and the United Kingdom. Beside academic institutions or ministries, it is often think tanks that use this method in order to influence public discourse. 
that in these institutions "comparative approaches to political research were endemic", many of these scholars engaged in wartime political analysis for the US government, "which placed them into an interdisciplinary enterprise" (Loewenberg 2006, 599).

\subsection{The institutionalisation of Austrian political science in the Second Republic}

After WWII, especially in the context of European reconstruction and the Cold War, the political relevance of USAmerican PS increased, particularly in problem-oriented research concerning issues like democratisation, nationbuilding and economic development. In the 1950s and I960s, US-American PS consolidated its "scientific identity" with seminal works of David Easton, Robert Dahl, Talcott Parsons and Karl Deutsch (Gunnell 2006, I44). The intellectual connections to continental Europe are worth noting, and illustrate the relevance and impact of interdisciplinary research programs that had been developed in the interwar period. ${ }^{5}$ It was Talcott Parsons, who had first translated Max Weber into English in 1949, contributing to the formation of a political research program on modernisation. ${ }^{6}$ Karl Deutsch came from a family that was firmly socialised within the (old) Austrian Social Democratic Party. In his work as political scientist, he built on the lineage of the Austro-Marxists, especially Otto Bauer. He also contributed to institutional innovation by setting up the Yale Political Data Program.

The evolution of US-American PS was marked by the accommodation of competing schools and the absorption of new developments in other disciplines. Prominent examples are the responses to "the complaint of the Caucus for a New Political Science against behavioralism in the I960s and I970s" and to "the Perestroika movement against rational choice in the 20oos" (Goodin 2OI3, 9). The result was internal diversification of the discipline and the foundation of two new journals by the American Political Science Association (PS and Perspectives on Politics). Recent innovative research in American PS comes from collaboration among multidisciplinary or interdisciplinary research teams and "from hybrid 'border-crossing' scholars" who move between disciplines (ibid., I2).

In Austria, the foundation of the Second Republic in 1945 created an opportunity to re-connect to the older

5 One lineage that strongly influenced US-American political science in the I950s was a version of positivism, which had been developed by the "Vienna Circle", in the tradition of Ernst Mach (1838-1916): "Mach had championed an Enlightenment vision of a unified interdisciplinary science, purified of metaphysics and in the service of humanistic and democratising reform" (Gunnell 2006, I42).

6 Within this research program, other political scientists contributed to the consolidation of sub-disciplines. Gabriel Almond, for instance, contributed to the field of comparative politics by providing codifications of knowledge on institutions like political parties, education and political culture (Almond 1990, 223). interdisciplinary tradition of Staatswissenschaft, as well as to the lineages developed by émigré political scientists in the United States. However, it turned out that Austrian political elites, organised in the ruling centreleft and centre-right parties, had no interest in the return of émigré scholars, nor in the establishment of an Austrian PS. The conservative minister of education, Heinrich Drimmel, who was in charge of Austrian universities, had studied law and was a student of Othmar Spann. In the interwar period, Spann was the leading conservative political philosopher, who popularised anti-empiricism and Romanticism through his university lectures and publications. This illustrates the continual hegemony of law and conservative-religious ideology, which were viewed by Drimmel (and other conservatives) as the source of legitimacy for the new republic (König/Ehs 2012, 215).

The most important attempt to establish a modern PS in Austria came from émigrés in the United States. In I963 Paul Lazarsfeld and Oskar Morgenstern, who had secured substantial funding from the Ford Foundation, eventually succeeded in founding the Institute for Advanced Studies (IHS, Institut für Höhere Studien) in Vienna. Morgenstern had studied economics in Vienna, where he succeeded Friedrich Hayek as director of the Österreichische Institut für Konjunkturforschung, one of the few remaining interdisciplinary research institutions. In 1938, Morgenstern had emigrated to the United States, where he became professor at Princeton University and received fame for his work on game theory (Leonhard 1998). Similarly, Paul Lazarsfeld, who drew on the lineage of Austro-Marxism, was a major innovator in the United States. With his pioneering work in applied social and political research, he shaped the study of public opinion, market research and electoral research. Through his research projects in the I940s he was not only able to advance social-science methodology, but also to recruit a number of European intellectuals and to raise socially critical issues about mass society (Barton 200I, 25I).

Established as an interdisciplinary research institution, the IHS in Vienna included PS, sociology and political economy. Drawing on his experience in the United States, where he had created the Bureau of Applied Social Research at Columbia University, Lazarsfeld knew about the importance of interdisciplinarity and cooperation. His own background is indicative: After his education as a mathematician at the University of Vienna, he worked at the Research Center for Economic Psychology (Wirtschaftspsychlogische Forschungsstelle), which had received funding from the Austrian labour movement to conduct a major study of unemployed workers. At Columbia, he was appointed professor in the department of sociology (Barton 200I, 246-249). The structure and work culture in the Bureau of Applied Social research re- 
flected Lazarsfeld's interdisciplinary approach to social and political research. It was characterised by structural and cognitive openness, evident in extensive discussions on cooperation and methodological innovation. In 200I, Columbia University's Provost Jonathan Cole, a former researcher in Lazarsfeld's Bureau of Applied Social Research, highlighted one of the major components of the Bureau's successful facilitation of collaboration among scholars from different disciplines (quoted in Barton 200I, 266):

"When the Bureau was at its peak, people would often spend I4 to I5 hours a day there, of which three of four hours were devoted to deep conversation with colleagues about the direction of the research."

Based upon a consensus of the subject to be investigated and shared epistemology, collaboration among scholars from multiple disciplines can stimulate creativity in problem-solving and dynamism in the development of theories and methods. As noted in the conceptual section of this paper, the question of doing multidisciplinary or interdisciplinary research is a question of degree. To be sure, although a dynamic model of interdisciplinary research has the potential to drive innovation, in practice it faces several obstacles, especially as it requires shared epistemology, ontology and the availability of sufficient time.

It is worth pointing out that the IHS in Vienna was founded in opposition to the "conservative" universities, to bring the US-American social science tradition, which was marked by interdisciplinary qualities, to Austria. In his "Report on Austria", which Lazarsfeld drafted for the Ford Foundation, he states that the conservative minister of education Drimmel "thinks we do not appreciate the spiritual values of the Austrian tradition (and) he felt that Americans are much more likely to help Germans because they too are materialistic" (quoted in Fleck 2000, I35). Drimmel's critique of "Western" materialism was also evident in his speech "Nobody lives by bread alone...", which he held at an international congress in 196I. There he criticised the politics in the "so-called free, but in reality almost completely state-owned society in the "free West" (quoted in König 2018, I88). This demonstrates the continued influence of Spann's metaphysics, which undermined the revival of the interdisciplinary social-science tradition of the interwar period. Drimmel sought to contain "modernity of thought in all its varieties, in order to retain and replenish the pool of conservatively minded professors" (König 2018, I82). Those conservative and radical right circles that had previously established conservative hegemony in the First Republic, regained their dominant position after 1945, shaping the future generations of Austrian academics and bureaucrats (ibid.).
The mission of the IHS can be described as a two-fold bridge function. As an institute of post-graduate studies, it educated the first generation of Austrian political scientists by connecting them to the US-American tradition, which was to be transplanted into the Austrian university system. At the same time, it was set up as an institution that promoted an interdisciplinary research programme, which shared in fact some of its roots with the Austrian social science tradition of the interwar period. Against this background, one can interpret it as a project of re-transplantation. Prominent examples of US-American professors teaching at the IHS, beside Lazarsfeld and Morgenstern, were the political scientists Karl Deutsch and Peter Katzenstein, who represent an intellectual lineage that can be traced back to Interwar Austria (Katzenstein 2014).

Despite grave problems during its first years (Fleck 2000), the IHS' mission of (re-)transplantation was eventually accomplished on the institutional level, when the first graduates, it had (co-)produced, became appointed to the newly founded PS chairs and departments in Vienna (197I), Salzburg (1971/75) and Innsbruck (1975) (Sickinger 2004, 47-54). Although the modernisation project of the so-called "Kreisky era" in the I970s had created favourable conditions for the establishment of Austrian PS at universities (Welan 1980), its "belated institutionalisation" (Pelinka 1996, I), and the remaining conservative ethos within the Austrian bureaucracy, led to a number of structural deficiencies. One was the remaining lack of cooperation between academic disciplines, as well as between PS and the administrativepolitical domain (König and Ehs 2012, 218-19).

Austrian PS appeared to lack interdisciplinary qualities, which undermined its capability in problem-oriented research and innovation, undermining its political, professional and civic relevance. It turned out that even the IHS itself failed to maintain its inter-disciplinary character, contrary to the initial plans of Lazarsfeld and the Ford Foundation. The IHS became increasingly dominated by applied economic research, statistics and modelling, reducing political economy to economics and narrowing the scope of PS (Kramer 2002, I24). This triggered a separation process between policy-oriented applied PS at the IHS and the mainstream of Austrian PS as it was taught at the University of Vienna (ibid.). While the latter rejected a focus on policy-orientation and the political-administrative domain, in recent years this gap was to some extent filled by the still existing Department of Staatswissenschaft (Government), which had been transferred from the faculty of law to the faculty of social science. 


\section{Barriers to problem orientation and interdisci- plinarity in Austrian Political Science after 1945}

In post-WWII Austria the following three factors, which undermined the formation of an innovative PS and prevented the reconnection to the older interdisciplinary tradition, can be identified.

The first factor was the political system. The conditions created by Austria's political system, which was characterised by neo-corporatism and party patronage, fostered a conservative and short-term approach in politics. This had negative consequences in terms of neglected university reforms, a general distaste for meritocratic principles and competition, as well as a lack of demand for policy-oriented research and innovation. Nowotny (1983, I89) describes the effects as follows: "Present policy-research often lacks past and future orientations. It is fitted into an existing and well-functioning institutional framework, in which the future has been subsumed under the present." Even during the supposedly highly successful Social Democratic reform era of the I970s, the development of the IHS as innovative social science institution suffered from the continual influence of party interests and the lack of an autonomous social science field (Fleck 20I7).

The second factor was the conservative structure of Austrian universities and higher education, which resulted in "autochthonous provincialisation" (Fleck 1996, 67 ). Resistance to change prevented structural and cognitive openness. Two remnants from the First Republic, which undermined the (re-)connection to émigrés and the international level after 1945, were the restored institutional dominance of conservative academics (König 2018) and anti-Semitism (Ash 2013, II7-I8). Austria's in-ward looking academic culture resulted in a general loss of innovation and a lack of internationalisation in the social sciences, despite several attempts by émigrés to collect funding and to start initiatives from abroad (Fleck 1996, 68).

On the level of departmental structures, a negative factor has been the steep hierarchy, which traditionally did not allow junior scholars to engage with professors as "peers" (Fleck 20II, 20). In the United States, flat hierarchies, diversity in faculty and interdisciplinarity of academic units and research programmes enhanced cooperation among peers, with positive consequences for the research form of "projects" (ibid., 23). New faculty members were not recruited by full professors but were selected by the departmental head, based on the criteria of diversity. A wider range of orientations had the advantage to increase appeals to the interest of students and to cooperate in research (ibid., 25).

The lack of interdisciplinarity on the institutional level in Austrian universities sheds light on why Otto Bauer's (1907)work on nationalism remained largely ne- glected in Austria, in contrast to the United States. Karl Deutsch became a prominent PS professor at Harvard University, teaching a variety of problem-oriented subjects within the field of "international relations". It was Benedict Anderson's notion of print capitalism in his seminal work Imagined Communities, which was deeply indebted to Otto Bauer's explanation of nationalism (Katzenstein 2014, 298). Ben Anderson's position in Cornell's "International Studies", created the conditions to engage with the question of nationalism. While his monograph became one of the most quoted social science books in history, Otto Bauer's study (1907)was translated into English only in the year 2000 (Bauer 2000).

The third major factor was the ideological legacy of conservative hegemony in the First Republic. An important barrier to cognitive openness was the perceived dichotomy between a "Western" materialist US-American PS, and the supposedly autochthonous Austrian tradition of dealing with political and state affairs either through legal studies or through metaphysical philosophy in the tradition of Spann. This dichotomy presented legal studies as necessary for the education of bureaucrats, while reducing political studies to philosophy.

This paper has deconstructed this narrative and identified common historical sources and intellectual lineages of inter-disciplinary scholarly traditions of political studies that had the potential to re-connect Austrian and US-American PS. In his presidential speech at the American Political Science Association, Karl Deutsch, who was intellectually influenced by AustroMarxists like Otto Bauer (Katzenstein 20I4, 298), argued that policy-oriented PS must not be reduced to a tool of governments (Deutsch 1971, 26):

"[T] he recent work of American political scientists has been somewhat one-sided. A fair amount of serious work has been done to provide policy advice for governments or their agencies, but much less has been done to provide specific policy information and proposals for non-governmental reform groups, civic organizations, labor unions, and the general public."

In fact, this perspective draws on the older traditions of Staatswissenschaft and Austro-Marxism, which suggest that political theory and political action are ideally connected. However, the perception of a dichotomy between empirical and normative interpretations of PS remains influential. It does not only result in the rejection of policy orientation, but further undermines the important aspect of professionalization in regard to establishing Austrian PS graduates as a recruitment pool for the political-administrative domain. 


\section{Are there any lessons to be learned?}

The findings of this paper support the argument that interdisciplinarity plays a critical role in the political, professional and civic relevance of PS. In those cases where PS has been institutionalised by drawing on the interdisciplinary tradition of science of the state, which had been particularly the case in the United States, France and Germany, this directly affected its political and professional relevance. In these countries, PS graduates became a major pool for the recruitment of bureaucrats and policy experts. Indirectly, this also affected its civic relevance, dependent on other factors such as the political ideological background of scholars and their willingness to engage in popular discourse.

Although interdisciplinary qualities enhance the capacity of PS to also increase its civic relevance, it does not necessarily result in a greater number of political scientists that fulfil the function of public intellectuals. As Karl Deutsch noted in his 197I lecture at the American Political Science Association, the production of policy-oriented research does not necessarily result in the engagement with socially critical issues and in the collaboration with civil society actors. Examples that show how interdisciplinarity feeds into civic relevance are the examples of the Austrian interwar period and the Italian case. The Austro-Marxist tradition informed a number of innovative political and social scientists, many of whom like Otto Bauer or Otto Neurath influenced public discourse, policies, as well as academic scholarship. A similar focus on their function as public intellectuals can be identified in the Italian case, where there was a broad consensus among political scientists to get involved in the political project of Italian nation-building as shapers of public discourse and politics.

The case of the IHS in Vienna serves as an example on the national level. Founded by Lazarsfeld, Morgenstern, and the Ford Foundation as an interdisciplinary institution of social and political research, it did not fully develop its interdisciplinary qualities, reducing the degree of interaction between subject matter, innovation in methodology, and theory. The growing lack of interdisciplinarity and cooperation resulted in a reduction of political, civic and professional relevance. When declining relevance of social sciences was identified at Columbia University, an attempt was launched in 200 I to revive the interdisciplinary tradition of Lazarsfeld's Bureau of Applied Social Research by creating a new Institute for Social and Economic Research and Policy, with a set of subject-oriented centres and interdisciplinary faculty teams: "Centers for Urban Research and Policy, Historical Social Science, Economic and Political Analysis, Decision Sciences, Study of Wealth and Inequality, Organizations and Digital Ecologies, and Science, Tech- nology and Environmental Policy" (Barton 200I, 266). ${ }^{7}$

That the relevance of PS is linked to interdisciplinary qualities appears particularly evident in the case of American PS. For instance, when after WWII economists turned to the study of politics this left a deep imprint on the discipline of PS. In 1969, the prominent political scientist Seymour Martin Lipset noted that much scholarship under the label of "political science" is in fact "the application of economic theory to politics" (Lipset I969, xv). In I970 Albert O. Hirschman (1970, 19-20) warned as an economist [sic!] that economists intruded the domain of PS:

"[R]eciprocity has been lacking in recent interdisciplinary work as economists have claimed that concepts developed for the purpose of analysing phenomena of scarcity and resource allocation can be successfully used for explaining political phenomena as diverse as power, democracy, and nationalism. They have thus succeeded in occupying large portions of the neighboring discipline while political scientists - whose inferiority complex vis-à-vis the tool-rich economist is equalled only by that of the economist vis-à-vis the physicist - have shown themselves quite eager to be colonized and have often actively joined the invaders."

It turned out that these developments have not been a one-way street in favour of the discipline of economics. As a growing number of political scientists adopted the methodological concepts from economics, they contributed to theoretical and methodological innovation in PS. Hirschman himself, who had begun his career as an economist, became eventually recognised as a prominent political sociologist (Goodin 2013, 33).

The example of International Relations (IR) after 1980 shows that with its growing strength in terms of identity, this sub-discipline acquired self-consciousness to draw on new methodological and theoretical developments in other disciplines. Ashworth $(2009,23)$ for instance highlights that although IR remained a central part of the PS curriculum, its interdisciplinary qualities after I980 enabled it to go beyond the traditional paradigms. It began to draw on new theoretical developments in other social science disciplines including neo-Marxism, feminism, postmodernism and constructivism. Similarly, the evolving set of methodologies used in IR has diversified and "the list of scholars doing IR now include historians, geographers, anthropologists and sociologists" (ibid.).

In conclusion, it seems appropriate to ask whether its extensive focus on the enforcement of disciplinary boundaries - a "closure" that was initially deemed necessary to enhance its legitimacy - continues to under-

7 For further information about this interdisciplinary research institute see the following website: http://iserp.columbia.edu (accessed 20.01.2018). 
mine the capability of Austrian PS to develop interdisciplinary qualities. Instead of opening up its disciplinary boundaries to tackle contemporary problems of "the state", "constitutionalism" and "democracy" from an empirical PS perspective, so-called "critical political science" has tended to focus on a normative perspective, yielding application and policy-oriented aspects to the discipline of law (Van Ooyen 2006, 7). The discipline of law, which in Austria is clearly demarcated from the social sciences, leaves substantial space for Austrian PS to address problems and applications in the field of public administration, regulation, citizenship, and so forth. A similar example represents the field of political economy. While basic and policy-oriented research was largely yielded to the discipline of economics, Austrian PS tended to focus predominantly on normative debates.

Institutional innovations such as the noted example of research clusters at Columbia University are also gaining ground in Austria. Examples are the institution of Gender Studies, Area Studies, and several interdisciplinary research platforms. The interdisciplinary field of Gender Studies has been particularly in the focus of political scientists at the University of Vienna and the University of Innsbruck (Sauer 2016). Through their institutionalisation in centres, Area Studies have the potential to support the development of innovative political research, diversifying PS as a discipline (Rodriguez 2016). One example is the Centre of South East European Studies at the University of Graz. Unlike centres, interdisciplinary research platforms are often temporary and linked to particular project funding, stimulating multidisciplinarity. An example is the platform "Religion and Transformation in Contemporary Society" at the University of Vienna, which includes scholars from PS, law, theology, cultural studies and education.

\section{References}

Arnold, Markus (2013), Interdisciplinary Research (Interdisciplinarity), in: Elias G. Carayannis (ed.), Encyclopedia of Creativity, Invention, Innovation and Entrepreneurship, New York: Springer, IIO5-III3.

Almond, Gabriel (1990), A Discipline Divided: Schools and Sects in Political Science, London: Sage.

Ash, Mitchell G. (20I3), Jüdische Wissenschaftlerinnen und Wissenschaftler an der Universität Wien von der Monarchie bis nach 1945, in: Oliver Ratholb (ed.), Der lange Schatten des Antisemitismus: Kritische Auseinandersetzungen mit der Geschichte der Universität Wien im 19. und 20. Jahrhundert, Göttingen: V\&R, 93-I22.

Barton, Allen H. (200I), Paul Lazarsfeld as Institutional Inventor, in: International Journal of Public Opinion Research, Vol. I3(3), 245-269.
Bauer, Otto (2000), The Question of Nationalities and Social Democracy, University of Minnesota Press: Minnesota.

Belkhoujaa, Mustapha/Hyungseok Yoonb (2018), How does openness influence the impact of a scholar's research? An analysis of business scholars' citations over their careers, in: Research Policy, Vol. 47(Io), 2037-2047.

Campbell, David F. J. (2019), Global Quality of Democracy as Innovation Enabler: Measuring Democracy for Success, New York, NY: Palgrave Macmillan (forthcoming).

Capano, Giliberto/Luca Verzichelli (2016), Looking for Eclecticism? Structural and Contextual Factors Underlying Political Science's Relevance Gap: Evidence from the Italian Case, in: European Political Science, Vol. I5(2), 2II-232.

CERI (1982), The University and the Community: The Problems of Changing Relationships, Paris: OECD.

Cherney, Adrian et al. (2013), Research Utilization in the Social Sciences: A Comparison of Five Academic Disciplines in Australia, in: Science Communication, Vol. 35(6), 780-809.

Deutsch, Karl W. (1971), On Political Theory and Political Action, in: American Political Science Review, Vol. 65(I), II-27.

Donovan, Claire/Phil Larkin (2006), The Problem of Political Science and Practical Politics, in: Politics, Vol. 26(I), II-I7.

Dvorak, Johann (20II), Joseph von Sonnenfels und die Wiedereinführung der Literarität in der HabsburgerMonarchie, in: J. Dvorak (ed.), Aufklärung, Demokratie und die Veränderung der gesellschaftlichen Verhältnisse, Vienna: Peter Lang, 19-32.

Ehs, Tamara (20IO), Über die Ursprünge österreichischer Politikwissenschaft - Ein Blick zurück im BolognaJahr 20Io, in: Austrian Journal of Political Science, Vol. 39(2), 223-24I.

Fleck, Christian (2002), "No Brains, No Initiative, No Collaboration" - The Austrian Case", in: International Sociology, Vol. I7(2), I99-2II.

Fleck, Christian (1996), Autochthone Provinzialisierung: Universität und Wissenschaftspolitik nach dem Ende der nationalsozialistischen Herrschaft in Österreich, in: Österreichische Zeitschrift für Geschichtswissenschaften, Vol. 7(I), 67-92.

Fleck, Christian (2000), Wie Neues nicht entsteht: Die Gründung des Instituts für Höhere Studien in Wien durch Ex-Österreicher und die Ford Foundation, in: Österreichische Zeitschrift für Geschichtswissenschaften, Vol. II(I), I29-I78.

Fleck, Christian (20II), A Transatlantic History of the Social Sciences: Robber Barons, the Third Reich and the Invention of Empirical Social Research, London: Bloomsbury. 
Fleck, Christian (20I7), Warum Wien nicht zum mitteleuropäischen (Ausbildungszentrum der empirischen Sozialwissenschaften wurde, in: Wolfgang L. Reiter et al. (eds), Wissenschaft, Technologie und industrielle Entwicklung in Zentraleuropa im Kalten Krieg, Vienna: LIT Verlag, I55-208.

Gibbons, Michael et al. (1994), The New Production of Knowledge: The Dynamics of Science and Research in Contemporary Societies, London: Sage.

Goodin, Robert E. (2013), The State of the Discipline, the Discipline of the State, in: R. E. Goodin (ed.), The Oxford Handbook of Political Science, Oxford: Oxford University Press, 3-57.

Gunnel, John G. (2006), The European Geneses of American Political Science, in: European Political Science, Vol. 5, I37-I49.

Heindl, Waltraud (20I3), Gehorsame Rebellen: Bürokratie und Beamte in Österreich, Vienna: Böhlau.

Heinisch, Reinhard (2004), Political Science between Intellectual Achievement, Critical Discourse and a Search for Relevance: Reflections on the State of the Discipline in Austria and the United States, in: Demokratie und Politik: 40 Jahre Politikwissenschaft in Österreich, Vienna: Peter Lang, 7I-98.

Hirschman, Albert (1970), Exit, voice, and loyalty: Responses to decline in firms, organizations, and states, Cambridge, MA: Harvard University Press.

Jeř́bek, Hynek (200I), Paul Lazarsfeld - The Founder of Modern Empirical Sociology: A Research Biography, in: International journal of public opinion research, Vol. I3(3), 229-244.

Kalberg, Stephen (2005), Max Weber: Readings and Commentary on Modernity, Oxford: Blackwell.

Katzenstein, Peter J. (20I4), Karl Deutsch: Teacher and scholar, in: International Relations, Vol. 28(3), 296-303.

Klein, J. T. (1990), Interdisciplinarity: History, Theory and Practice, Detroit: Wayne State University Press.

König, Thomas (20II), Das unvollständige Projekt: Bestandsaufnahme der österreichischen Politikwissenschaft, in: Austrian Journal of Political Science, Vol. 4O(I), $8 \mathrm{I}-89$.

König, Thomas (2018), A Strategy of Containment: Heinrich Drimmel's Political Activism in the Realm of Higher Education Policy in the Early Second Republic, in: Österreichische Zeitschrift für Geschichtswissenschaften, Vol. 29(I), I80-205.

König, Thomas/Tamara Ehs (2012), Wissenschaft von der Politik vor der Politikwissenschaft?, in: Austrian Journal of Political Science, Vol. 4I(2), 2 I I-227.

Kramer, Helmut (2002), Wie Neues doch entstanden ist: Zur Gründung und zu den ersten Jahren des Instituts für Höhere Studien in Wien, in: Österreichische Zeitschrift für Geschichtswissenschaften, Vol. I3(3), IIOI32.
Leonard, Robert J. (1998), Ethics and the Excluded Middle: Karl Menger and Social Science in Interwar Vienna, in: The History of Science Society, Vol. 89(I), I-26.

Lipset, Seymour M. (1969), Politics and the Social Sciences - Introduction, in: S. M. Lipset (ed.), Politics and the Social Sciences, New York: Oxford University Press, vii-xxii.

Loewenberg, Gerhard (2006), The Influence of European Émigré Scholars on Comparative Politics, I925-1965, in: American Political Science Review, Vol. Ioo(4), 597604 .

Montricher, Nicole de (1989), French Political Science, in: PS: Political Science \& Politics, March, I46-I 48.

Müller, Karl H. (1996), Sozialwissenschaftliche Kreativität in der Ersten und Zweiten Republik, in: Österreichische Zeitschrift für Geschichtswissenschaften, Vol. $7(\mathrm{I}), 9-43$.

Nowotny, Helga (1983), Marienthal and After: Local Historicity and the Road to Policy Relevance, in: Knowledge, Vol. 5(2), I69-I92.

Pelinka, Anton (1996), Politikwissenschaft in Österreich, in: Swiss Political Science Review, Vol. 2(4), I-I2.

Poggi, Gianfranco (1990), The State: Its Nature, Development and Prospects, Cambridge: Polity Press.

Rodriguez, Monica de Luna (2016), Area studies diversifying European political science? Perspectives from Germany and Portugal, in: European Political Science, Vol. I5, 519-535.

Sauer, Birgit (2016), Austrian exceptionalism? Insights from a huge department in a small country, in: European Political Science, Vol. 15, 332-342.

Senn, Martin/Franz Eder (2018), The Relevance of (Austrian) Political Science: A Conceptual Framework, in: Austrian Journal of Political Science, Vol. 47(3), I-I7.

Sickinger, Hubert (2004), Die Entwicklung der österreichischen Politikwissenschaft", in: Demokratie und Politik: 40 Jahre Politikwissenschaft in Österreich, Vienna: Peter Lang, 27-69.

Smith, Rogers M. (2015), Political Science and the Public Sphere Today, in: Perspectives on Politics, Vol. I3(2), 366376.

Stimmer, Gernot (1997), Eliten in Österreich, I848-I970, Vienna: Böhlau.

Van den Besselaar, P./G. Heimericks (200I), Disciplinarity, Multidisciplinarity, Interdisciplinarity - Concepts and Indicators. Paper to 8th Conference on Scientometrics and Informetrics, Sydney Australia, I620/7/OI.

Van Ooyen, Robert Christian (2006), Politik und Verfassung: Beiträge $\mathrm{zu}$ einer politikwissenschaftlichen Verfassungslehre, Springer: Wiesbaden.

Wagner, Caroline S. et al. (2OII), Approaches to understanding and measuring interdisciplinary scientific research (IDR): A review of the literature, in: Journal of Informetrics, Vol. I65, I4-26. 
Wagner, Peter (1990), Sozialwissenschaften und Staat: Frankreich, Italien, Deutschland I870-I980, Frankfurt: Campus Verlag.

Warleigh-Lack, Alex / Michelle, Cini (2009), Interdisciplinarity and the study of politics, in: European Political Science, Vol. 8, 4-I5.

Wasserman, Janek (2014), Black Vienna: The Radical Right in the Red City, I9I8-I938, Ithaca: Cornell University Press.

Welan, Manfried (1980), 5 Jahre UOG, in: Austrian Journal of Political Science, Vol. 3, 373-76.

Wood, Matthew (2014), Bridging the Relevance Gap in Political Science, in: Politics, Vol. 34(3), 275-286.

\section{Authors}

Philipp Decker is a lecturer in European Politics at the Social Sciences University of Ankara (ASBU). He holds a $\mathrm{PhD}$ from the London School of Economics, where he completed his studies in the Department of Government. Prior to this, he received a MA in nationalism studies from the Central European University Budapest and a diploma in political science from the University of Vienna. Currently he works on a monograph about stateand nation-building in central Europe. His research interests include populism, state-building, and the politics of nation-building.

David Campbell is a lecturer and "Privat-Dozent" in Political Science at the University of Vienna and a Higher Education Researcher and Manager in the Department for Continuing Education Research and Educational Management, Center for Educational Management and Higher Education Development, at the Danube University Krems. His articles on knowledge, innovation, knowledge economy and democracy have been published in several international journals.

Jürgen Braunstein is a postdoctoral fellow at Harvard Kennedy School's Belfer Center where he works on the Geopolitics of Energy Project. His research focuses on the drivers as well as consequences of the green energy 'revolution' for the global energy composition and its implications for existing and future interstate relations. Juergen is currently finishing a book on the politics and the variation of sovereign wealth (under contract with Michigan University Press). He has a B.A. from the University of Vienna and a masters and doctorate from the London School of Economics. 